\title{
Distant regions underpin interregional flows of cultural ecosystem services provided by birds and mammals
}

\author{
Matthias Schröter $\mathbb{D}$, Roland Kraemer $\mathbb{D}$, Roy P. Remme $\mathbb{D}$, \\ Alexander P. E. van Oudenhoven $(D$
}

Received: 15 February 2019/Revised: 27 June 2019/Accepted: 7 September 2019/Published online: 24 September 2019

\begin{abstract}
Ecosystem service assessments rarely consider flows between distant regions. Hence, telecoupling effects such as conservation burdens in distant ecosystems are ignored. We identified service-providing species for two cultural ecosystem services (existence and bequest, and birdwatching) and two receiving, i.e. benefitting, regions (Germany, the Netherlands). We delineated and analysed sending, i.e. service-providing, regions on a global scale. The proportion of service-providing species with distant habitats was higher for birdwatching (Germany: 58.6\%, Netherlands: 59.4\%), than for existence and bequest (Germany: 49.3\%, Netherlands: $57.1 \%$ ). Hotspots of sending regions were predominantly situated in tropical and subtropical grasslands, savannas and shrublands and were significantly more threatened and poorer than the global mean. Hotspot protection levels for flows to Germany were higher than the global mean, and lower for the Dutch hotspots. Our findings increase understanding on how distant regions underpin ecosystem services and necessitate interregional assessment as well as conservation efforts.
\end{abstract}

Keywords Biodiversity conservation

Ecosystem service flows - Service-providing species ·

Sustainability $\cdot$ Telecoupling

\section{INTRODUCTION}

Spatial assessments of ecosystem services (ES) rarely consider benefits from distant areas through flows of ES to

Electronic supplementary material The online version of this article (https://doi.org/10.1007/s13280-019-01261-3) contains supplementary material, which is available to authorized users. the studied region, and in turn, how these flows affect distant regions (Pascual et al. 2017). Interregional ES flows are defined as movements of goods, energy and information derived from ecosystems between a region providing the service, i.e. the sending region, and a region using the service, i.e. the receiving region (Schröter et al. 2018). ES often flow over large distances and hence 'telecouple' distant sending and receiving regions (Schröter et al. 2018; Koellner et al. 2019). Telecoupling refers to processes that interlink distant regions through material or immaterial flows of energy, matter or information (Liu et al. 2015). Climate change, land-use change or overexploitation in a sending region might undermine continued ES provision in a receiving region. For example, the destruction of breeding habitat for migratory birds in a sending region might affect population numbers and ES provision like pest control or opportunities for leisure hunting in distant receiving regions (López-Hoffman et al. 2017). As some ES rely on conservation mechanisms, for instance through protection of key service-providing species (Luck et al. 2009), interregional ES flows also pose equity questions. Some countries bear costs of conservation while other regions benefit. Studying interregional ES flows could hence identify inequitable distributions of these costs and benefits (Schröter et al. 2018). This is of particular relevance when regions in the Global South are bearing costs while the Global North benefits (Martín-López et al. 2018). The regional assessment report for Europe and Central Asia of IPBES (Intergovernmental Science-Policy Platform on Biodiversity and Ecosystem Services) identified interregional ES flows as a key knowledge gap (Martín-López et al. 2018). Thus, to date ES assessments provide a limited picture of the dependence of ES on ecosystems abroad (Pascual et al. 2017). Yet, Schröter et al. (2016) found that 
national ecosystem assessments in Europe cover interregional ES flows to a minor extent.

Exceptions include studies of provisioning ES that are traded goods, such as timber (Kastner et al. 2011), crops (Yu et al. 2013) and fishery products (Watson et al. 2015). Also, some studies have addressed passive biophysical flows of regulating services such as carbon sequestration (Serna-Chavez et al. 2014) or migrating species that provide pollination (López-Hoffman et al. 2010) and pest control (López-Hoffman et al. 2014). The largest knowledge gaps remain for interregional flows of cultural ES (Martín-López et al. 2018; Koellner et al. 2019), which comprise non-material contributions of ecosystems to human well-being. Finding suitable indicators and developing methods for cultural ES is already challenging within case-study boundaries (Milcu et al. 2013), and even more so when quantifying interregional flows. Schröter et al. (2018) distinguish two types of flows that are relevant for cultural ES. First, cultural ES flows comprise the movement of migratory species between sending and receiving regions, which provide opportunities to experience wildlife, such as through birdwatching. Second, cultural ES flows comprise the transmission of information as the basis for cognitive, non-material use, such as aesthetic appreciation, spiritual activities and inspiration for art.

Challenges remain in quantifying interregional flows for cultural ES. For instance, it is difficult to identify and characterise landscapes or ecosystems, i.e. environmental spaces (Fish et al. 2016), that provide cultural ES in interaction with cultural practices. Examples are value attribution to certain species, or active use through observation and enjoyment. Data on how cultural practices relate to specific places are scarce; methods need to be developed to delineate the regions that are linked through flows (Koellner et al. 2019). Distant sending regions can have an existence or bequest value for receiving regions, i.e. their persistence is important to present or future generations (Hansjürgens et al. 2017). In addition, these spaces can provide valuable breeding or wintering areas for migratory birds that provide opportunities for birdwatching elsewhere (López-Hoffman et al. 2017).

Another challenge remains in linking ES assessments more strongly to biodiversity (Schröter et al. 2016). Different aspects of biodiversity are of different importance for quantifying cultural ES directly (Harrison et al. 2014). For instance, species richness can be directly valued as a cultural ES, as done by birdwatchers (Karp et al. 2015; Cumming and Maciejewski 2017). Furthermore, the persistence of iconic, charismatic species or landscapes is appreciated by people who hold existence and bequest values (Schirpke et al. 2018). Iconic species are often highlighted by conservation organisations as culturally valued species to justify and attract funding (Bowen-Jones and Entwistle 2002). While the cultural role of such species and landscapes for supporting identities is conceptually acknowledged (Díaz et al. 2018), large-scale quantification approaches are still lacking.

To address these challenges, our study aims to identify and characterise sending regions for interregional flows of two understudied cultural ES. We selected existence and bequest values that people have for bird and mammal species, and birdwatching. These two ES go beyond the most regularly studied cultural ES of eco-tourism and more mainstream recreational activities, such as hiking. Moreover, the selected cultural ES are relevant and prominent examples for which interregional ES flows are thought to play a major role (Liu et al. 2015; López-Hoffman et al. 2017). Both can be directly linked to service-providing species for which sufficient data are available.

To achieve this objective, we delineate sending and receiving regions to infer interregional flows of existence and bequest values and birdwatching for two receiving regions, Germany and the Netherlands. Both countries are well-suited examples of highly developed countries with strongly modified ecosystems due to high population density and intense land use. Also, both countries are important stepstones for migratory birds, being located in transatlantic flyways and hosting widespread wetlands particularly in the Netherlands (Kirby et al. 2008). Neither country included interregional ES flows in their latest national ecosystem assessments (Schröter et al. 2016).

We develop indicators for the flow of the two cultural ES and delineate the respective sending regions. We then compare the most important sending regions ('hotspots') for both countries in terms of their location, equity implications due to potential costs of conservation. We also consider threat to these hotspots as well as their protection status. We also analyse the distance between sending and receiving regions. Finally, we reflect on the implications of our research, with specific attention for transferability of the methods and policy relevance of our findings.

\section{MATERIALS AND METHODS}

\section{Cultural ecosystem service indicators and range maps of service-providing species}

We collected data on cultural ES indicators for the period of 2012-2016 for Germany and the Netherlands. All data sources can be found in the Appendix (Table S1). Because each indicator involves both the value attribution and the species providing the cultural ES, this makes them suitable as ES indicators (Milcu et al. 2013; Fish et al. 2016). Interregional flows of ES occur if ranges of the service- 
providing species are distant from the respective receiving region, i.e. not having any spatial overlap (Fig. 1).

For existence and bequest we selected the indicator appearance of species in annual reports of large nature conservation organisations. Species conservation involves existence and bequest value aspects, as people support conservation irrespective of a direct use (Davidson 2013). Existence and bequest values of species have been suggested as indicators to more strongly link ES to biodiversity (Reyers et al. 2012). For Germany, we analysed the annual reports of NABU, the German partner of Birdlife International and Friends of the Earth Germany. We included reports of sub- or partner-organisations with a national heritage and international focus (Table S1). For the Netherlands, we analysed reports of Natuurmonumenten, WNF (the Dutch branch of the World Wildlife Fund WWF) and Vogelbescherming (the Dutch partner of Birdlife International) (Table S1). In total, we studied 40 reports and recorded all species mentioned in relation to conservation efforts. Due to data limitations on range maps for many taxa, we limited our search to birds and mammals. The search was further limited to non-extinct, nondomesticated species. Note that we infer interregional flows of this cultural ES through the distance between sending and receiving regions, but do not quantify the frequency or intensity of information flows, nor do we link this to species abundance.

For birdwatching, we selected the indicator number of registered bird observation events on online birding platforms. For Germany, we used eBird, a global bird observation database and currently the best publicly available dataset for Germany, containing around 290,000 observations (noting at least one individual at a time, Table S1). For the Netherlands we used data from waarneming.nl, a widely used database for observations of different species (Table S1). The dataset contained around 16.7 million bird observations. We took the top 300 bird species ranked by number of observations. Selecting a common threshold based on ranked lists was necessary to compensate for the difference in size between the Dutch and German datasets. The Dutch database contained a much higher number of observations and hence a higher number of entries (1168containing a high number of occasionally occurring species) than the German list (397). An equal number of considered species ensured comparability for further analyses. After sorting out (sub)species that are not listed with range data in the IUCN database, 297 species for Germany, and 286 species for the Netherlands were included in our analysis. Note that we infer interregional flows of this cultural ES through a distance between sending and

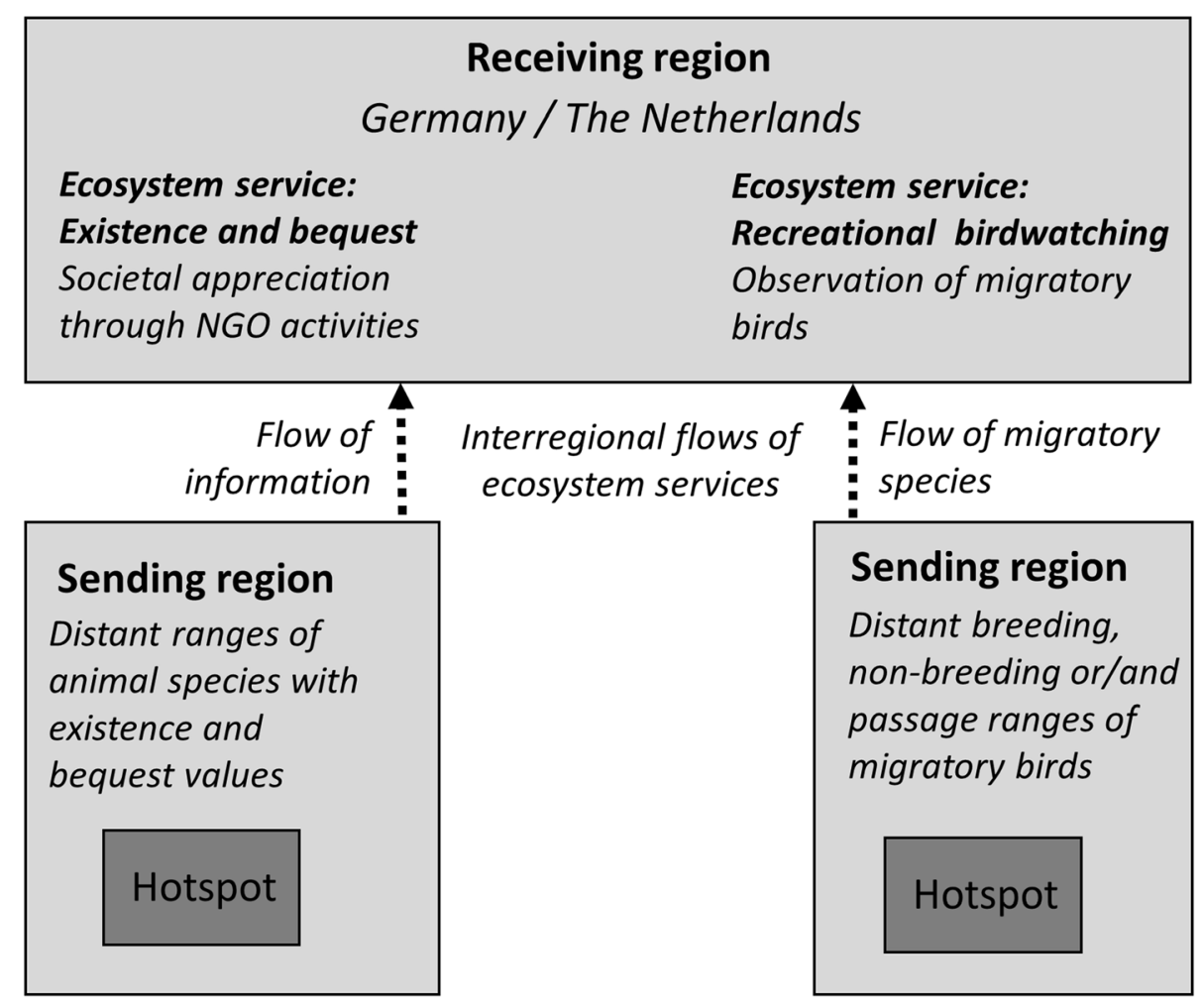

Fig. 1 Conceptual approach of the study. Two types of interregional flows between sending regions and receiving regions for two cultural ecosystem services. Spatial analyses are performed for respective hotspots, i.e. sub-regions representing the ca. top $2 \%$ quantile spatial coverage, sorted by number of co-occurring species (cf. Table 2) 
receiving regions, but do not quantify the abundance of migratory birds actually moving between these areas as such data are very scarce.

\section{Sending regions for cultural ecosystem services: range maps for service-providing species}

The potential spatial extent of a species' occurrence is delineated by range maps (IUCN 2018). We obtained maps for all service-providing species included in our analysis (Table S1). To approximate interregional flows, we identified species with ranges distant from the receiving countries. 'Distant' areas for existence and bequest included species that did not overlap with either receiving country. For migratory birds, we included seasonal areas that did not overlap with either receiving countries.

For birds, we acquired range maps from Birdlife International. For mammals we used the IUCN Red List of Threatened Species. We included only range maps that were 'extant', 'probably extant' and 'possibly extant'. To determine interregional flows we distinguished species with distant ranges from resident species in either country. Resident species have their year-round range at least partly inside either country. For the analysis of existence and bequest, we assumed no interregional flows for migratory bird areas with the seasonal functions "breeding", "non-breeding", "passage" that overlapped with either of the receiving countries. We also assumed this for all areas outside the receiving countries with the same seasonal function as the overlapping areas. Distant areas for existence and bequest hence included species ranges that did not overlap with either country. For birdwatching, we included all seasonal areas within a $200 \mathrm{~km}$ buffer of the respective country to account for occasional appearances, potential shifts and uncertainties in both range maps and flyways. We then extracted distant areas with a seasonal function that were not also present within the receiving country and that were within two major flyways overlapping Central Europe (Blacksea/Mediterranean and East Atlantic, Kirby 2010). We excluded those species for which two seasonal areas overlapped with the respective country (i.e. migration partly takes place within a country). The two relevant flyways overlapped with populations in the northern part of North America and Greenland. As some populations migrate southwards from there across the Americas rather than to Germany or the Netherlands, we checked per population for evidence on migration to Europe, with the help of the Encyclopedia of Life fact sheets (EOL 2018).

\section{Spatial analyses of sending region hotspots}

We overlapped all range maps, i.e. sending regions, on a $100 \times 100 \mathrm{~km}$ grid. Coarse resolutions of range maps have been shown to reduce overestimations of actual species occurrences and hence better reflect the actual accuracy of these range maps (Hurlbert and Jetz 2007). For further analyses, we delineated sending region hotspots as areas with high importance, defined as high species overlaps. We iteratively searched for an upper quantile of the overlay raster that led to similarly large, spatially restricted hotspot extents ( $2 \%$ of all pixels). Due to break values, the delineated area was slightly higher than $2 \%$.

We quantified coverage of fourteen terrestrial biomes for the hotspot areas, as delineated by Olson et al. (2001). To identify potential threats to species in the sending regions we took the human footprint and calculated mean values and proportions within classes for each hotspot. The human footprint is an aggregated index of human impact on ecosystems ranging from zero to 50, the latter indicating the highest impact (Venter et al. 2016). We also created a measure approximating the actual distance between sending and receiving regions. We calculated the mean Euclidean distance between Germany and the Netherlands to the centroid of each range map polygon (coherent occurrence area) of all distant species.

Conservation is needed to ensure that sending regions continue to provide habitat for service-providing species. Hence, we assessed the conservation status by quantifying the proportion of sending region hotspots that coincide with different levels of protection of the World Database on Protected Areas. To address potential equity issues, we analysed mean income and proportion of five income levels within sending region hotspots by spatializing Worldbank country data on Gross Domestic Product (GDP, current US\$ per capita). Each $100 \times 100 \mathrm{~km}$ grid cell was assigned the respective country value for GDP (mean value of territory underlying each grid cell). Note that the global mean calculated in this way is spatially weighted, thus influenced by countries with a larger surface area. This measure is not to be confused with a global GDP per capita value. To test statistical differences between the means of the GDP and human footprint values of each hotspot and the global sample, we performed a (non-parametric) two sample Kolmogorov-Smirnov test (SPSS v. 24).

\section{RESULTS}

We found widespread interregional flows both for existence and bequest, and birdwatching. Out of all identified service-providing species, the proportion of distant species was higher for birdwatching (Germany: 58.6\%, Netherlands: $59.4 \%$ ) than for existence and bequest (Germany: 49.3\%, Netherlands: $57.1 \%$ ). Full lists of distant species can be found in the Appendix (Table S2 and S3). 
Table 1 Top most-mentioned distant species (number of reports) for which existence and bequest are held for Germany and the Netherlands

\begin{tabular}{|c|c|c|c|}
\hline & Latin name & English name & Number of reports \\
\hline \multicolumn{4}{|c|}{ Germany } \\
\hline 1. & Grus grus & Common crane & 16 \\
\hline 2. & Haliaeetus albicilla & White-tailed eagle & 13 \\
\hline 3. & Pandion haliaetus & Osprey & 12 \\
\hline 4. & Vanellus vanellus & Northern lapwing & 12 \\
\hline 5. & Ciconia nigra & Black stork & 10 \\
\hline 6. & Panthera tigris (incl. Panthera tigris sumatrae) & Tiger, incl Sumatran tiger & 9 \\
\hline 7. & Ciconia ciconia & White stork & 8 \\
\hline 8. & Panthera leo & Lion & 8 \\
\hline \multirow[t]{4}{*}{9.} & Alcedo atthis & Common kingfisher & 7 \\
\hline & Uрира ерорs & Hoopoe & \\
\hline & Cephalorhynchus hectori maui & Maui's dolphin & \\
\hline & Panthera uncia & Snow Leopard & \\
\hline \multicolumn{4}{|c|}{ The Netherlands } \\
\hline 1. & Loxodonta africana (incl. Loxodonta cyclotis) & African elephant (incl African forest elephant) & 9 \\
\hline 2. & Limosa limosa & Black-tailed godwit & 9 \\
\hline 3. & Tringa totanus & Common redshank & 8 \\
\hline 4. & Panthera tigris (incl. Panthera tigris altaica and Panthera tigris tigris) & Tiger (incl. Siberian tiger and Bengal tiger) & 7 \\
\hline 5. & Haliaeetus albicilla & White-tailed eagle & 7 \\
\hline 6. & Platalea leucorodia & Eurasian spoonbill & 7 \\
\hline 7. & Vanellus vanellus & Northern lapwing & 7 \\
\hline \multirow[t]{6}{*}{8.} & Alcedo atthis & Common kingfisher & 6 \\
\hline & Botaurus stellaris & Bittern & \\
\hline & Haematopus ostralegus & Eurasian oystercatcher & \\
\hline & Mareca penelope & Eurasian wigeon & \\
\hline & Recurvirostra avosetta & Pied avocet & \\
\hline & Tyto alba & Western barn owl & \\
\hline
\end{tabular}

\section{Existence and bequest}

Relative to mammals, birds are the dominant distant species for which existence and bequest values are held. Of the 130 distant species found for Germany, 108 were birds and 22 were mammals. Of the 166 distant species for the Netherlands, 127 were birds and 39 were mammals. 65 species were common among the sending regions of both countries. The most-mentioned distant species are shown in Table 1.

We found distinct spatial patterns of cultural ES sending regions based on different service-providing species ranges and richness for Germany and the Netherlands (Fig. 2). The majority of sending regions for Germany were in Africa, and to a smaller extent in South Asia. The regions mainly included habitats for terrestrial bird and mammal species. For the Netherlands, sending regions with highest richness were situated in Africa, Northern Eurasia and South Asia and included ranges of several marine species. For Germany, species ranges covered marine areas by less than $10 \%$. In contrast, two-thirds of range areas of distant species found for the Netherlands were located in seas (cf. Figure 2, Table 2). Species ranges for the German case were on average located further away than for the Dutch case $(7320 \mathrm{~km}$ vs. $6330 \mathrm{~km}, p<0.001)$.

Sending region hotspots for Germany and the Netherlands were predominantly situated in the biomes Tropical and Subtropical Grasslands, and Savannas Shrublands (Table 2). For the Dutch case, boreal forests and taiga, temperate broadleaf and mixed forests and temperate grasslands. Savannas and shrublands also covered relatively high proportions of sending region hotspots (Table 2). The mean human footprint was higher in sending region hotspots linked to the Netherlands compared to the German case 


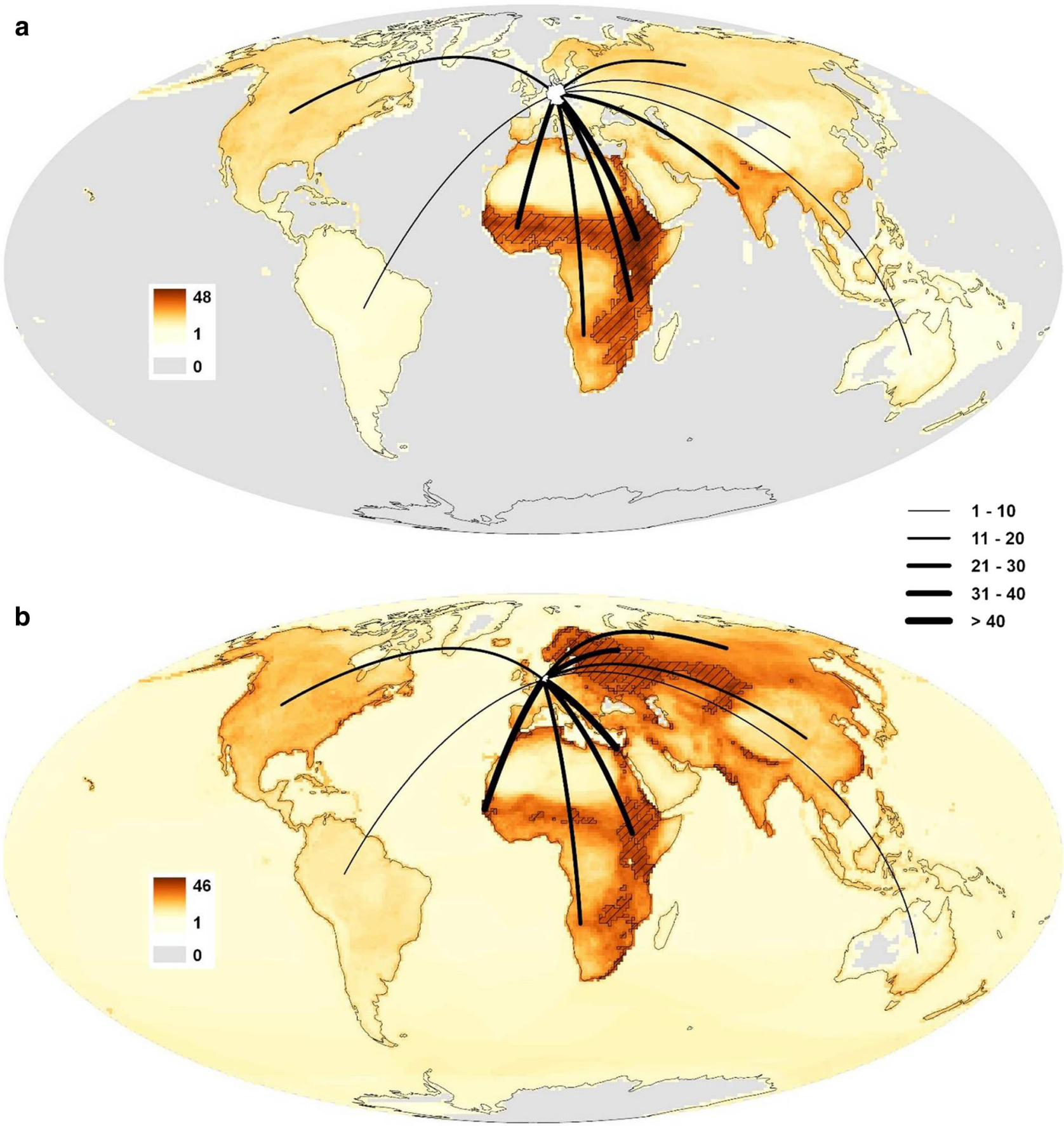

Fig. 2 Sending regions for existence and bequest. Intersection of gridded range maps of distant species for which existence and bequest values were found in Germany (a) and the Netherlands (b) (colour scale represents the number of co-occurring species). Dashed areas were classified as hotspots (top $2 \%$ quantiles of total earth surface, cf. Table 2 for exact values). Curved black lines illustrate flows from exemplary sending regions, where line widths represent value ranges of co-occurring species in the respective sending region, i.e. in the wider vicinity of line origins. Note: these lines are meant for illustration of flows between sending and receiving regions, and were created by choice in order to represent different continents as well as regions by number of species and in order to achieve an overall convenient visual arrangement. Projection: World Mollweide, EPSG:54009 (Datum: WGS84)

$(p<0.001)$, and for both countries sending region hotspots human footprint values were higher than the global mean (6.28, $p<0.001$ ) (Fig. 3). A higher proportion of the sending region hotspots for Germany was formally protected (20.0\%), compared to the Netherlands (13.4\%). The sending region hotspots for Germany also had a considerably lower 
Table 2 Statistics for the hotspots for existence and bequest and birdwatching in the sending regions for Germany and the Netherlands

\begin{tabular}{|c|c|c|c|c|}
\hline Criteria & $\begin{array}{l}\text { Existence and bequest } \\
\text { (Germany) }\end{array}$ & $\begin{array}{l}\text { Existence and bequest } \\
\text { (Netherlands) }\end{array}$ & Birdwatching (Germany) & $\begin{array}{l}\text { Birdwatching } \\
\text { (Netherlands) }\end{array}$ \\
\hline No. of distant species & 130 (mammals and birds) & 166 (mammals and birds) & 174 (birds) & 170 (birds) \\
\hline $\begin{array}{l}\text { Relation terrestrial: marine area } \\
\text { of range maps }\end{array}$ & $10: 1$ & $1: 2$ & $1.75: 1$ & $1.15: 1$ \\
\hline Hotspot area $\left(1000 \mathrm{~km}^{2}\right)$ & $\begin{array}{l}11,310 \text { (top } 2.21 \% \\
\text { quantile, } 30-48 \\
\text { species) }\end{array}$ & $\begin{array}{l}11,010 \text { (top } 2.15 \% \\
\text { quantile, } 33-46 \\
\text { species) }\end{array}$ & $\begin{array}{l}10,740 \text { (top } 2.10 \% \\
\text { quantile, } 37-65 \\
\text { species) }\end{array}$ & $\begin{array}{l}11,460 \text { (top } 2.24 \% \\
\text { quantile, } 39-61 \\
\text { species) }\end{array}$ \\
\hline \multirow[t]{7}{*}{$\begin{array}{l}\text { Coverage of (top 5) biomes in } \\
\text { sending region hotspots ( } \% \text { of } \\
\text { hotspot in parentheses) }\end{array}$} & $\begin{array}{l}\text { Tropical and subtropical } \\
\text { grasslands, savannas } \\
\text { shrublands }(74.5 \%)\end{array}$ & $\begin{array}{l}\text { Tropical and subtropical } \\
\text { grasslands, savannas } \\
\text { shrublands }(20.9 \%)\end{array}$ & $\begin{array}{l}\text { Tropical and subtropical } \\
\text { grasslands, savannas } \\
\text { shrublands }(64.0 \%)\end{array}$ & $\begin{array}{l}\text { Tropical and subtropical } \\
\text { grasslands, savannas } \\
\text { shrublands }(37.3 \%)\end{array}$ \\
\hline & \multirow{2}{*}{$\begin{array}{l}\text { Tropical and subtropical } \\
\text { moist broadleaf forests } \\
(8.1 \%)\end{array}$} & $\begin{array}{l}\text { Boreal forests/taiga } \\
(17.4 \%)\end{array}$ & $\begin{array}{l}\text { Deserts and xeric } \\
\text { shrublands }(9.7 \%)\end{array}$ & $\begin{array}{l}\text { Boreal forests/taiga } \\
(24.1 \%)\end{array}$ \\
\hline & & \multirow{2}{*}{$\begin{array}{l}\text { Temperate broadleaf and } \\
\text { mixed forests }(15.9 \%)\end{array}$} & \multirow{2}{*}{$\begin{array}{l}\text { Mediterranean forests, } \\
\text { woodlands and scrub }\end{array}$} & \multirow{2}{*}{$\begin{array}{l}\text { Deserts and xeric } \\
\text { shrublands }(7.1 \%)\end{array}$} \\
\hline & Deserts and xeric & & & \\
\hline & $\begin{array}{l}\text { Montane grasslands and } \\
\text { shrublands }(4.0 \%)\end{array}$ & $\begin{array}{l}\text { Temperate grasslands, } \\
\text { savannas and } \\
\text { shrublands }(14.5 \%)\end{array}$ & \multirow{3}{*}{$\begin{array}{l}\text { Tropical and subtropical } \\
\text { moist broadleaf forests } \\
(5.3 \%) \\
\text { Flooded grasslands and } \\
\text { savannas }(3.7 \%)\end{array}$} & $\begin{array}{l}\text { Temperate grasslands, } \\
\text { savannas and } \\
\text { shrublands }(4.1 \%)\end{array}$ \\
\hline & \multirow{2}{*}{$\begin{array}{l}\text { Flooded grasslands and } \\
\text { savannas }(3.9 \%)\end{array}$} & \multirow{2}{*}{$\begin{array}{l}\text { Deserts and xeric } \\
\text { shrublands }(6.5 \%)\end{array}$} & & \multirow{2}{*}{$\begin{array}{l}\text { Mediterranean forests, } \\
\text { woodlands and scrub } \\
(3.4 \%)\end{array}$} \\
\hline & & & & \\
\hline $\begin{array}{l}\text { Average euclidean distance of } \\
\text { distant species }(1000 \mathrm{~km})\end{array}$ & 7.3 & 6.3 & 2.8 & 2.6 \\
\hline
\end{tabular}

mean GDP per capita (1424 US\$) than the hotspots for the Netherlands $(10,327$ US\$, $p<0.001)$, and both hotspots were considerably lower than the global spatially weighted mean (19,419 US\$, $p<0.001)$ (Fig. 3).

\section{Birdwatching}

The migratory bird species that were most often observed by birdwatchers are shown in Table 3 . The sending regions of Germany and the Netherlands had 134 species in common. The two countries had distinct patterns of sending regions, i.e. distant ranges of service-providing species that contribute to birdwatching (Fig. 4). Important sending regions for both countries were situated in Africa and Northern Europe. Additionally, Northern Eurasia, Southern Europe and the Middle East hosted important distant seasonal areas for migratory birds. However, Germany's hotspots were located nearly exclusively in Africa, while hotspots for the Netherlands were divided over Africa and Northern Eurasia. Average distance to sending regions was larger for Germany than for the Netherlands $(2800 \mathrm{~km}$ vs. $2562 \mathrm{~km}, p<0.001$ ), and considerably smaller compared to sending regions for existence and bequest for both countries.

Sending region hotspots were predominantly situated in the biome Tropical and Subtropical Grasslands, Savannas and Shrublands for both receiving countries (Table 2), with a higher coverage of the latter for Germany. The boreal forests and taiga biome covers a relatively large part of the
Dutch sending region. The mean human footprint in German hotspots was higher than in Dutch hotspots, and, as for existence and bequest, footprints in both hotspots were higher than the global mean $(6.28, p<0.001)$ (Fig. 3). A higher proportion of German hotspots were formally protected than Dutch hotspots (15.5\% vs. $12.6 \%)$. The average spatially weighted GDP showed comparable results to existence and bequest. The German hotspots were located in considerably poorer regions (2071 US\$) than the Dutch hotspots (8813 US\$, $p<0.001$ ), and both were poorer than the global mean $(19,419$ US $\$, p<0.001)$ (Fig. 3).

\section{DISCUSSION}

Our findings demonstrate the importance of distant regions for providing habitats for species that underpin two cultural ES, namely existence and bequest, and birdwatching. A considerable proportion of species appreciated for their existence and bequest or for birdwatching purposes have habitats in distant regions. Hence, a strong link exists between biodiversity in distant regions and cultural ES in receiving countries.

Our findings suggest that existence and bequest values are intimately linked to conservation activities performed by the analysed conservation organisations. This is in line with other studies that found preferences for distant species (e.g. Barua 2011). This preference phenomenon has led to, for instance, the distinction of the African "Big Five" 

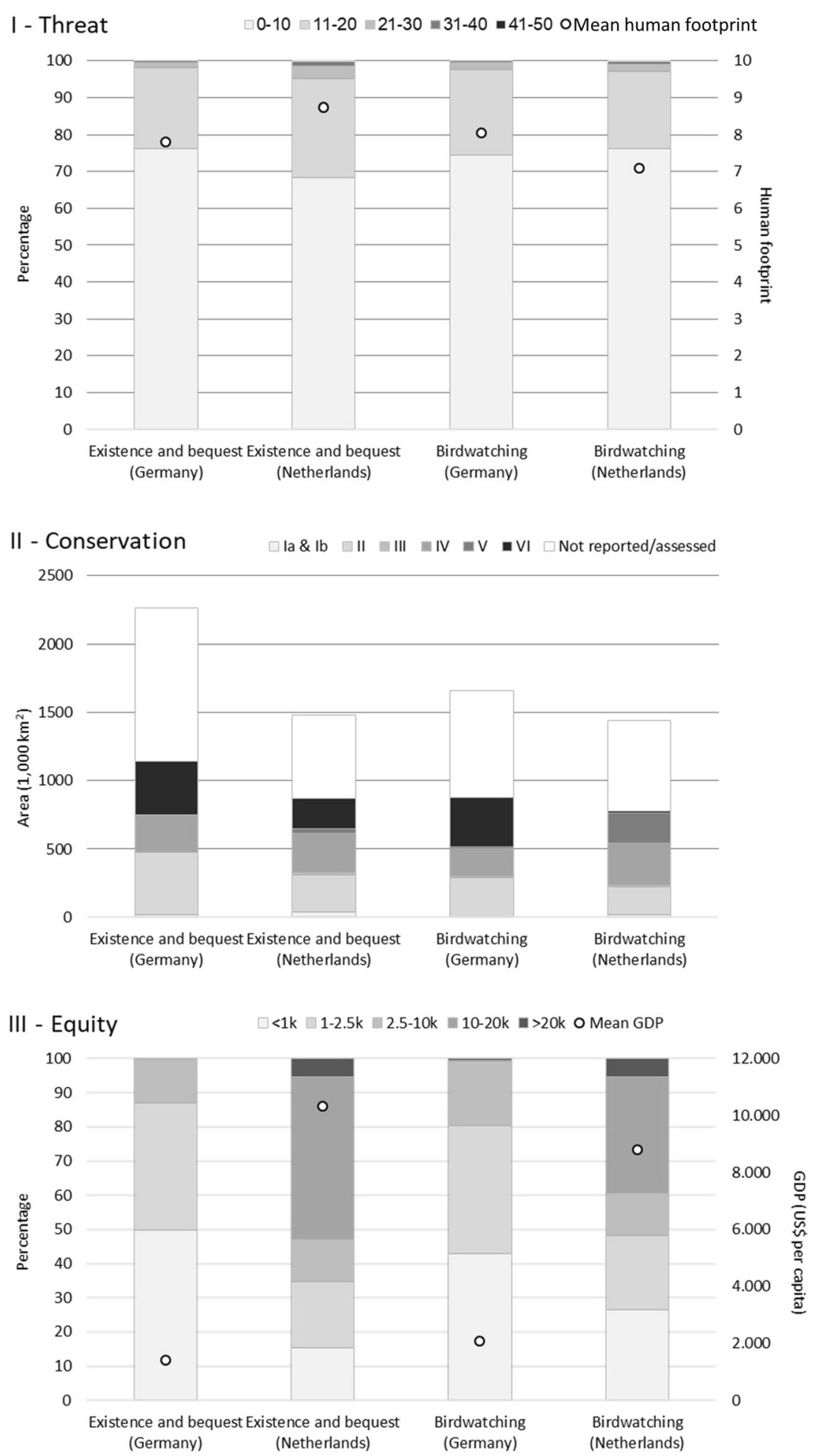

Fig. 3 Threat, conservation and equity of cultural ES in Germany and the Netherlands. I-Threat shows the percentage of sending region hotspots in a Human Footprint category (left axis) and the mean Human Footprint (right axis) per cultural ES in Germany and the Netherlands. II-Conservation shows the area $\left(1000 \mathrm{~km}^{2}\right)$ of sending region hotspots that fall within an IUCN conservation status class per cultural ES in Germany and the Netherlands. III-Equity shows the percentage of sending region hotspots in a GDP per capita category (left axis) and the mean GDP per capita per (right axis) per cultural ES in Germany and the Netherlands

(Williams et al. 2000), most of which also feature in our results for existence and bequest. Other studies on interregional flows of cultural ES have so far focused on single, selected species, e.g. migrating Monarch butterfly 
(Danaus plexippus) (Semmens et al. 2018) or information flows on the giant panda (Ailuropoda melanoleuca) (Liu et al. 2015). In contrast, we have performed analyses based on indicators for two countries but covering a large number of species. This complements existing research on the appreciation of a set of iconic, charismatic species through different indicators (Courchamp et al. 2018; Schirpke et al. 2018).

For existence and bequest, we found a slightly higher share of distant species for the Netherlands than for Germany. This might relate to the relative smaller size of the country and scarcity of natural areas providing habitat for resident species, and to the fact that the Dutch Wadden Sea is an important part of the migration route of many of the birds migrating between Northern Eurasia and the Netherlands (Boere and Piersma 2012). Our findings contribute to the emerging literature on the importance of migratory birds for providing cultural ES. The importance of migratory birds for birdwatching has been exemplified before (López-Hoffman et al. 2017), but few studies have systematically analysed spatial implications related to observations of migratory birds. Mattsson et al. (2018) analysed birdwatching of northern pintails (Anas acuta) along migration routes. Our study, in contrast, identified a large number of species and focused on identifying spatial patterns and characteristics of sending regions. We are aware of other factors that play a role in birdwatching, such as rarity (Booth et al. 2011), threat and endemism (Steven et al. 2017) and variety (Cumming and Maciejewski 2017). However, observation numbers are sufficient for the purpose of demonstrating dependencies of birdwatching on remote habitats for breeding, wintering or resting during passage.

Our indicators represent two aspects of cultural ES: value attribution indicators (species in reports and on birding sites) and spatial representation indicators (range maps), which together allow us to quantitatively infer cultural ES flows. Future research could incorporate abundance of species, which has been largely neglected in ES research so far. However, we note that such data are limited and restricted to a small number of species.

Table 3 The ten most observed distant species by birdwatchers for Germany and the Netherlands

\begin{tabular}{|c|c|c|c|}
\hline Pos. & Latin name & English name & Times observed (in 1000) \\
\hline \multicolumn{4}{|c|}{ Germany } \\
\hline 1. & Turdus merula ${ }^{\mathrm{a}}$ & Common blackbird & 10.1 \\
\hline 2. & Sturnus vulgaris & Common starling & 5.5 \\
\hline 3. & Erithacus rubecula & European robin & 5.3 \\
\hline 4. & Buteo buteo & Common buzzard & 5.2 \\
\hline 5. & Phylloscopus collybita & Common chiffchaff & 4.7 \\
\hline 6. & Motacilla alba & White wagtail & 4.2 \\
\hline 7. & Fulica atra & Eurasian coot & 4.0 \\
\hline 8. & Sylvia atricapilla & Eurasian blackcap & 3.8 \\
\hline 9. & Falco tinnunculus & Common kestrel & 3.4 \\
\hline 10. & Hirundo rustica & Barn swallow & 3.3 \\
\hline \multicolumn{4}{|c|}{ The Netherlands } \\
\hline 1. & Buteo buteo & Common buzzard & 437.7 \\
\hline 2. & Ardea alba & Great egret & 310.5 \\
\hline 3. & Ardea cinerea & Grey heron & 233.3 \\
\hline 4. & Phylloscopus collybita & Common chiffchaff & 209.0 \\
\hline 5. & Vanellus vanellus & Northern lapwing & 200.2 \\
\hline 6. & Aythya fuligula & Tufted duck & 181.1 \\
\hline 7. & Haematopus ostralegus & Eurasian oystercatcher & 171.3 \\
\hline 8. & Motacilla alba & White wagtail & 150.8 \\
\hline 9. & Hirundo rustica & Barn swallow & 149.2 \\
\hline 10. & Mareca strepera & Gadwall & 145.5 \\
\hline
\end{tabular}

${ }^{\mathrm{a}}$ This species is predominantly resident in Germany, but remained in the analysis due to the search corridor that included migratory populations of the species in Eastern Europe 


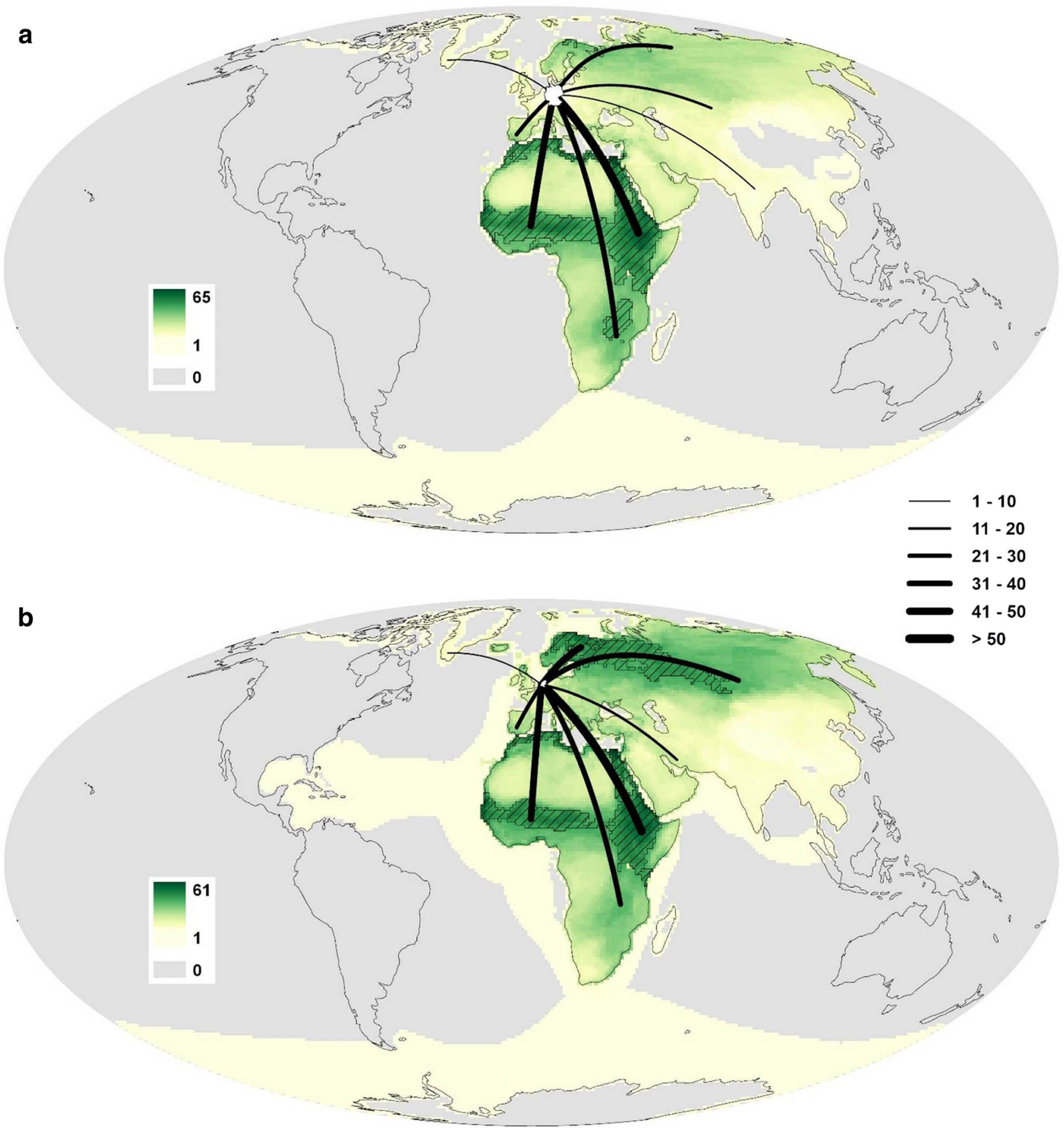

Fig. 4 Sending regions for birdwatching. Intersection of gridded range maps of distant species appreciated by birdwatching in Germany (a) and the Netherlands (b) (colour scale represents the number of co-occurring species). Dashed areas were classified as hotspots (top 2\% quantiles of total earth surface, cf. Table 2 for exact values). Curved black lines illustrate flows from exemplary sending regions, where line widths represent value ranges of co-occurring species in the respective sending region, i.e. in the wider vicinity of line origins. Note: these lines are meant for illustration of flows between sending and receiving regions, and were created by choice in order to represent different continents as well as regions by number of species and in order to achieve an overall convenient visual arrangement. Projection: World Mollweide, EPSG:54009 (Datum: WGS84)

By delineating sending regions we have identified ecosystems and landscapes that contribute to the environmental basis for human well-being in receiving regions.
This approach has also been suggested by Koellner et al. (2019), and could be applied to analyse other ES that depend on service-providing migratory species, such as 
pest control or pollination (López-Hoffman et al. 2017). Indicators such as those used in this study could be used for assessments in other countries, especially because international datasets are also available (e.g. iNaturalist). International studies would require substantial language skills to distill local species names from the conservation reports.

For birdwatching we accessed vast citizen science driven birdwatching databases. The use of such data resembles research applying social media data to analyse other ES, such as different forms of recreation (Willemen et al. 2015; Hausmann et al. 2018). Mentionings of species have, in similar contexts, been applied to gather data for cultural ES (Karp et al. 2015; Schirpke et al. 2018).

Countries indirectly rely on distant ecosystems when they harness interregional flows of cultural ES. Such dependencies could be analysed further by introducing an external footprint measure for cultural ES, comparable to ecological footprints (Borucke et al. 2013) and other measures for material and energy appropriation from ecosystems (Dorninger et al. 2017). Such a measure could be seen as land required for non-material purposes, analogous to land or resources embodied in material consumption (Meyfroidt et al. 2013). For instance, the sending region hotspots hosting a high number of species that contribute to existence and bequest or birdwatching in Germany and the Netherlands, cover around 11 million $\mathrm{km}^{2}$ of the Earth's surface. Area assessment based solely on range maps is likely an overestimation, as range maps do not precisely predict actual occurrence of a species (Rondinini et al. 2011), and hence needs refinement in future studies. Moreover, future research could analyse the effect of shifts in actual species occurrences within and beyond current ranges due to environmental factors such as climate change.

We showed that sending regions for existence and bequest and birdwatching for both receiving regions were significantly poorer than the global average. This raises questions of interregional distributive justice related to ES (Schröter et al. 2018), as the costs of conserving serviceproviding species habitat would need to be covered by poor regions, while richer receiving regions benefit. To raise awareness in the respective countries about this issue, consequences of value attribution could be communicated through indicators like threat or conservation level, to make explicit which distant regions would require additional conservation efforts supported by both Germany and the Netherlands, for example. This issue could be related to the European Union Habitats and Birds Directives, which are policy instruments that feature interregional aspects of species conservation. Apart from the ratification of the Convention on Biological Diversity and its resulting Aichi biodiversity targets, global policy instruments that explicitly target distant service-providing species remain scarce. In fact, the most targeted efforts seem to be undertaken by the non-governmental organisations from which our data originated, as they are running conservation and development projects in many sending regions (e.g. the Dutch WWF, NABU International). For example, the Dutch Vogelbescherming ran land management projects in the Sahel, Western Africa, to promote sustainable farming methods and conserve migratory bird habitat (Vogelbescherming 2016), thus indirectly supporting Dutch birdwatchers. Future studies could analyse to what extent actual conservation efforts by non-governmental organisations spatially match sending region hotspots. Our results could also help to spatially target regions in which conservation efforts benefit a higher number of respective species, but are currently not focal areas of international conservation efforts (López-Hoffman et al. 2017). We showed that sending regions were significantly more threatened by human impact than the global average. Through such threats a telecoupling could take place, in which drivers in a sending region affect the benefits related to ES flows in a receiving region (Schröter et al. 2018). Our study design, however, did not allow us to link the impacts of threats to reduced bird populations and a consequent reduction in birdwatching. Different types of threats (e.g. land use, pollution) are known to harm migratory birds in habitats within their flyways (Kirby et al. 2008); our chosen global threat measure (Venter et al. 2016) approximates these threats.

Courchamp et al. (2018) showed that charismatic mammals are culturally valued in different forms in European countries, while at the same time being threatened in their home ranges. Conservation measures, for instance the establishment of protected areas, could help, but are not guaranteed to reduce threats (Jones et al. 2018). We found that the share of sending region hotspots for Germany covered by protected areas (20.0\%) was slightly above the global average (14.9\%, UNEP-WCMC and IUCN 2018). For the Netherlands, this share (13.4\%) is slightly below the global average. Such conservation efforts that also support the survival of service-providing species, can be interpreted as off-stage ES burdens as framed by Pascual et al. (2017), with potential implications for access and recognition of local people (Martin et al. 2016).

\section{CONCLUSION}

This study demonstrates that distant regions make a clear contribution to the provision of cultural ES and hence contribute to human well-being. By using transferable spatial indicators we found pronounced interregional flows 
of cultural ES for existence and bequest and for birdwatching. Furthermore, this study identified direct links between biodiversity and cultural ES. Our findings contribute to on-going work on extending (inter)national ecosystem assessments with an interregional component and increase understanding on how distant regions underpin ES used by a country. The considerable differences we found between the sending regions for Germany and the Netherlands implicate the importance of individual national efforts to assess interregional flows.

We also showed that consideration of interregional ES flows matters as it helps to identify potential international equity concerns relating to the distribution of benefits and costs of providing and receiving ES. Sending region hotspots for cultural ES for Germany and the Netherlands are poorer and more threatened than the global average. This analysis can underpin international conservation efforts and policies to sustain flows of these cultural ES over time. Our findings could be used to clarify that external land is used to provide cultural ES, and to raise awareness of potential interregional dependencies and responsibilities.

Acknowledgements We thank two anonymous reviewers for their constructive comments which have helped to improve an earlier version of the manuscript. We thank Morgan Kain for critical feedback and for checking the language. The work by RK is supported by the research project Environmental-Health Interactions in Cities (GreenEquityHEALTH) - Challenges for Human Well-Being under Global Changes (2017-2022), funded by the German Federal Ministry of Education and Research (BMBF; no. 01LN1705A). RPR is supported by the Marianne and Marcus Wallenberg Foundation. The work by AvO was funded by the STW research programme 'Naturedriven nourishment of coastal systems (NatureCoast)' (Grant Number 12691), which is (partly) financed by the Netherlands Organisation for Scientific Research (NWO).

\section{REFERENCES}

Barua, M. 2011. Mobilizing metaphors: The popular use of keystone, flagship and umbrella species concepts. Biodiversity and Conservation 20: 1427-1440.

Boere, G.C., and T. Piersma. 2012. Flyway protection and the predicament of our migrant birds: A critical look at international conservation policies and the Dutch Wadden Sea. Ocean and Coastal Management 68: 157-168.

Booth, J.E., K.J. Gaston, K.L. Evans, and P.R. Armsworth. 2011. The value of species rarity in biodiversity recreation: A birdwatching example. Biological Conservation 144: 2728-2732.

Borucke, M., D. Moore, G. Cranston, K. Gracey, K. Iha, J. Larson, E. Lazarus, J.C. Morales, et al. 2013. Accounting for demand and supply of the biosphere's regenerative capacity: The national footprint accounts' underlying methodology and framework. Ecological Indicators 24: 518-533.

Bowen-Jones, E., and A. Entwistle. 2002. Identifying appropriate flagship species: The importance of culture and local contexts. Oryx 36: 189-195.
Courchamp, F., I. Jaric, C. Albert, Y. Meinard, W.J. Ripple, and G. Chapron. 2018. The paradoxical extinction of the most charismatic animals. PLoS Biology 16: e2003997.

Cumming, G.S., and K. Maciejewski. 2017. Reconciling community ecology and ecosystem services: Cultural services and benefits from birds in South African National Parks. Ecosystem Services 28: 219-227.

Davidson, M.D. 2013. On the relation between ecosystem services, intrinsic value, existence value and economic valuation. Ecological Economics 95: 171-177.

Díaz, S., U. Pascual, M. Stenseke, B. Martín-López, R.T. Watson, Z. Molnár, R. Hill, K.M.A. Chan, et al. 2018. Assessing nature's contributions to people. Science 359: 270-272.

Dorninger, C., D.J. Abson, J. Fischer, and H. von Wehrden. 2017. Assessing sustainable biophysical human-nature connectedness at regional scales. Environmental Research Letters 12: 055001.

EOL. 2018. Encyclopedia of life. Retrieved 25 May 2018, from http:// www.eol.org/.

Fish, R., A. Church, and M. Winter. 2016. Conceptualising cultural ecosystem services: A novel framework for research and critical engagement. Ecosystem Services 21: 208-217.

Hansjürgens, B., C. Schröter-Schlaack, A. Berghöfer, and N. Lienhoop. 2017. Justifying social values of nature: Economic reasoning beyond self-interested preferences. Ecosystem Services 23: 9-17.

Harrison, P.A., P.M. Berry, G. Simpson, J.R. Haslett, M. Blicharska, M. Bucur, R. Dunford, B. Egoh, et al. 2014. Linkages between biodiversity attributes and ecosystem services: A systematic review. Ecosystem Services 9: 191-203.

Hausmann, A., T. Toivonen, R. Slotow, H. Tenkanen, A. Moilanen, V. Heikinheimo, and E.D. Minin. 2018. Social media data can be used to understand tourists' preferences for nature-based experiences in protected areas. Conservation Letters 11: e12343.

Hurlbert, A.H., and W. Jetz. 2007. Species richness, hotspots, and the scale dependence of range maps in ecology and conservation. Proceedings of the National Academy of Sciences 104: 13384-13389.

IUCN. 2018. 1994 Categories \& criteria (version 2.3). Retrieved 25 May 2018, from http://www.iucnredlist.org/static/categories criteria_2_3.

Jones, K.R., O. Venter, R.A. Fuller, J.R. Allan, S.L. Maxwell, P.J. Negret, and J.E.M. Watson. 2018. One-third of global protected land is under intense human pressure. Science 360: 788-791.

Karp, D.S., C.D. Mendenhall, E. Callaway, L.O. Frishkoff, P.M. Kareiva, P.R. Ehrlich, and G.C. Daily. 2015. Confronting and resolving competing values behind conservation objectives. Proceedings of the National Academy of Sciences 112: 11132-11137.

Kastner, T., K.-H. Erb, and S. Nonhebel. 2011. International wood trade and forest change: A global analysis. Global Environmental Change 21: 947-956.

Kirby, J. 2010. Review of current knowledge of bird flyways, principal knowledge gaps and conservation priorities. Prepared on behalf of the CMS Scientific Council/Working Group on Flyways. UNEP Convention on Migratory Species of Wild Animals, Bonn, Germany.

Kirby, J.S., A.J. Stattersfield, S.H.M. Butchart, M.I. Evans, R.F.A Grimmett, V.R. Jones, J. O'Sullivan, G.M. Tucker, et al. 2008. Key conservation issues for migratory land- and waterbird species on the world's major flyways. Bird Conservation International 18: S49-S73.

Koellner, T., A. Bonn, S. Arnhold, K.J. Bagstad, D. Fridman, C.A. Guerra, T. Kastner, M. Kissinger, et al. 2019. Guidance for assessing interregional ecosystem service flows. Ecological Indicators 105: 92-106. 
Liu, J., V. Hull, J. Luo, W. Yang, W. Liu, A. Viña, C. Vogt, Z. Xu, et al. 2015. Multiple telecouplings and their complex interrelationships. Ecology and Society 20 (3): 44.

López-Hoffman, L., C.C. Chester, D.J. Semmens, W.E. Thogmartin, M.S. Rodriguez McGoffin, R. Merideth, and J.E. Diffendorfer. 2017. Ecosystem services from transborder migratory species: Implications for conservation governance. Annual Review of Environment and Resources 42: 509-539.

López-Hoffman, L., R.G. Varady, K.W. Flessa, and P. Balvanera. 2010. Ecosystem services across borders: A framework for transboundary conservation policy. Frontiers in Ecology and the Environment 8: 84-91.

López-Hoffman, L., R. Wiederholt, C. Sansone, K.J. Bagstad, P. Cryan, J.E. Diffendorfer, J. Goldstein, K. LaSharr, et al. 2014. Market forces and technological substitutes cause fluctuations in the value of bat pest-control services for cotton. PLOS ONE 9: e87912.

Luck, G.W., R. Harrington, P.A. Harrison, C. Kremen, P.M. Berry, R. Bugter, T.R. Dawson, F.D. Bello, et al. 2009. Quantifying the contribution of organisms to the provision of ecosystem services. BioScience 59: 223-235.

Martín-López, B., A. Church, E. Başak Dessane, P. Berry, C. Chenu, M. Christie, M. Gerino, H. Keune, et al. 2018. Chapter 2: Nature's contributions to people and quality of life. In The IPBES regional assessment report on biodiversity and ecosystem services for Europe and Central Asia, ed. M. Rounsevell, M. Fischer, A. Torre-Marin Rando, A. Mader, and IPBES, 57-185. Bonn, Germany: Secretariat of the Intergovernmental SciencePolicy Platform on Biodiversity and Ecosystem Services.

Martin, A., B. Coolsaet, E. Corbera, N.M. Dawson, J.A. Fraser, I. Lehmann, and I. Rodriguez. 2016. Justice and conservation: The need to incorporate recognition. Biological Conservation 197: 254-261.

Mattsson, B.J., J.A. Dubovsky, W.E. Thogmartin, K.J. Bagstad, J.H. Goldstein, J.B. Loomis, J.E. Diffendorfer, D.J. Semmens, et al. 2018. Recreation economics to inform migratory species conservation: Case study of the northern pintail. Journal of Environmental Management 206: 971-979.

Meyfroidt, P., E.F. Lambin, K.-H. Erb, and T.W. Hertel. 2013. Globalization of land use: Distant drivers of land change and geographic displacement of land use. Current Opinion in Environmental Sustainability 5: 438-444.

Milcu, A.I., J. Hanspach, D. Abson, and J. Fischer. 2013. Cultural ecosystem services: A literature review and prospects for future research. Ecology and Society 18 (3): 44.

Olson, D.M., E. Dinerstein, E.D. Wikramanayake, N.D. Burgess, G.V.N. Powell, E.C. Underwood, J.A. D’Amico, I. Itoua, et al. 2001. Terrestrial ecoregions of the world: A new map of life on EarthA new global map of terrestrial ecoregions provides an innovative tool for conserving biodiversity. BioScience 51: 933-938.

Pascual, U., I. Palomo, W. Adams, K.M.A. Chan, T. Daw, E. Garmendia, E. Gómez-Baggethun, R. de Groot, et al. 2017. Offstage ecosystem service burdens: A blind spot for global sustainability. Environmental Research Letters 12: 075001.

Reyers, B., S. Polasky, H. Tallis, H.A. Mooney, and A. Larigauderie. 2012. Finding common ground for biodiversity and ecosystem services. BioScience 62: 503-507.

Rondinini, C., M. Di Marco, F. Chiozza, G. Santulli, D. Baisero, P. Visconti, M. Hoffmann, J. Schipper, et al. 2011. Global habitat suitability models of terrestrial mammals. Philosophical Transactions of the Royal Society B Biological Sciences 366: 2633-2641.

Schirpke, U., C. Meisch, and U. Tappeiner. 2018. Symbolic species as a cultural ecosystem service in the European Alps: Insights and open issues. Landscape Ecology 33: 711-730.
Schröter, M., C. Albert, A. Marques, W. Tobon, S. Lavorel, J. Maes, C. Brown, S. Klotz, et al. 2016. National ecosystem assessments in Europe: A review. BioScience 66: 813-828.

Schröter, M., T. Koellner, R. Alkemade, S. Arnhold, K.J. Bagstad, K.H. Erb, K. Frank, T. Kastner, et al. 2018. Interregional flows of ecosystem services: Concepts, typology and four cases. Ecosystem Services 31: 231-241.

Semmens, D.J., J.E. Diffendorfer, K.J. Bagstad, R. Wiederholt, K. Oberhauser, L. Ries, B.X. Semmens, J. Goldstein, et al. 2018. Quantifying ecosystem service flows at multiple scales across the range of a long-distance migratory species. Ecosystem Services 31: $255-264$.

Serna-Chavez, H., C. Schulp, P. van Bodegom, W. Bouten, P. Verburg, and M. Davidson. 2014. A quantitative framework for assessing spatial flows of ecosystem services. Ecological Indicators 39: 24-33.

Steven, R., J.C.R. Smart, C. Morrison, and J.G. Castley. 2017. Using a choice experiment and birder preferences to guide bird-conservation funding. Conservation Biology 31: 818-827.

UNEP-WCMC and IUCN. 2018. The lag effect in the world database on protected areas. Retrieved 25 May 2018, from https://www. protectedplanet.net/c/the-lag-effect-in-the-world-database-onprotected-areas.

Venter, O., E.W. Sanderson, A. Magrach, J.R. Allan, J. Beher, K.R. Jones, H.P. Possingham, W.F. Laurance, et al. 2016. Sixteen years of change in the global terrestrial human footprint and implications for biodiversity conservation. Nature Communications 7: 12558 .

Vogelbescherming. 2016. Jaarverslag 2016, p. 116.

Watson, R.A., B.S. Green, S.R. Tracey, A. Farmery, and T.J. Pitcher. 2015. Provenance of global seafood. Fish and Fisheries 17: $585-595$.

Willemen, L., A.J. Cottam, E.G. Drakou, and N.D. Burgess. 2015. Using social media to measure the contribution of red list species to the nature-based tourism potential of African protected areas. PLOS ONE 10: e0129785.

Williams, P.H., N.D. Burgess, and C. Rahbek. 2000. Flagship species, ecological complementarity and conserving the diversity of mammals and birds in sub-Saharan Africa. Animal Conservation 3: 249-260.

Yu, Y., K. Feng, and K. Hubacek. 2013. Tele-connecting local consumption to global land use. Global Environmental Change 23: $1178-1186$.

Publisher's Note Springer Nature remains neutral with regard to jurisdictional claims in published maps and institutional affiliations.

\section{AUTHOR BIOGRAPHIES}

Matthias Schröter $(\bowtie)$ is a postdoctoral researcher at UFZ Helmholtz Centre for Environmental Research. His work focuses on spatial modelling and assessment of ecosystem services, the analysis of the science-policy interface on ecosystem services and biodiversity and conceptual development of ecosystem services.

Address: Department of Ecosystem Services, UFZ - Helmholtz Centre for Environmental Research, Permoserstr. 15, 04318 Leipzig, Germany.

Address: German Centre for Integrative Biodiversity Research (iDiv) Halle-Jena-Leipzig, Deutscher Platz 5e, 04103 Leipzig, Germany. e-mail: matthias.schroeter@ufz.de

Roland Kraemer is a $\mathrm{PhD}$ candidate at Geography Department, Humboldt-Universität zu Berlin. He works on mapping and assessment of ecosystem services and biodiversity using in situ observations, GIS and remote sensing. 
Address: Department of Ecosystem Services, UFZ - Helmholtz Centre for Environmental Research, Permoserstr. 15, 04318 Leipzig, Germany.

Address: German Centre for Integrative Biodiversity Research (iDiv) Halle-Jena-Leipzig, Deutscher Platz 5e, 04103 Leipzig, Germany.

Address: Institute of Geography, Humboldt-Universität zu Berlin, Unter den Linden 6, 10099 Berlin, Germany.

e-mail: roland.kraemer@hu-berlin.de

Roy P. Remme is a Postdoctoral researcher with the Natural Capital Project at Stanford University. He works on quantifying the value of biodiversity and ecosystem services, specifically in urban systems. Furthermore, he specialises in ecosystem services modelling, ecosystem accounting and spatial analysis.

Address: Natural Capital Project, Stanford University, 371 Serra Mall, Stanford, CA 94305, USA.
Address: National Institute for Public Health and the Environment (RIVM), PO Box 1, 3720 BA Bilthoven, The Netherlands.

e-mail: royremme@stanford.edu

Alexander P. E. van Oudenhoven is an assistant professor at the Institute of Environmental Sciences, Leiden University. He works on evaluating the outcomes of ecological engineering and landscape management in terms of ecosystem services and other contributions to human well-being, with a strong focus on developing stakeholderrelevant indicators.

Address: Institute of Environmental Sciences CML, Leiden University, Einsteinweg 2, 2333 CC Leiden, The Netherlands. e-mail: a.p.e.van.oudenhoven@cml.leidenuniv.nl 